considered included various combinations of the following words: smoking, tobacco, nicotine, journal, international, prevention, cessation, reduction, problems, disease, and health.

We chose Tobacco Control for three main reasons: (a) it reflects our intention to focus on the control of the problem, as opposed to effects of tobacco use on disease processes; (b) it subsumes the major interventions in this area, including public education, prevention, cessation, and policy; and (c) it is pithy, as are the names of other journals published by the BMJ Publishing Group for example, Eye, Gut, and Thorax. In the masthead on the front and back cover of the journal, we have added "An International Journal" as a subtitle to emphasise our goal to include material from throughout the world.

The issue you raise, though, is an important one. "Control" has many meanings. When people hear "tobacco control", do they think of control by government, by a "smoking police", by "smoking Nazis" (a term used recently by a spokesman for Newt Gingrich, Speaker of the US House of Representatives $^{1}$ )? Or do they think of wellintended efforts to reduce tobacco use, appropriate regulation of the manufacture and marketing of tobacco products, or control of behaviour by nicotine?

The Random House Dictionary of the English Language (unabridged edition) provides 16 definitions of "control", one of which is particularly relevant to tobacco control: "prevention of the flourishing or spread of something undesirable: rodent control" (emphasis in original). ${ }^{2}$

"Control" also seems to be an accepted, if not standard, term in public health circles. One of the leading textbooks in public health has included chapters entitled "Communicable disease control", "Occupational and environmental health control", and "Smoking: health effects and control", 3 The US Centers for Disease Control and Prevention has a National Center for Injury Prevention and Control, a Division of Cancer Prevention and Control, and a Measles Control Unit. ${ }^{4}$ A directory of state public health agencies shows "control" in the names of many of their organisational units, including "Radiation Control" (Alabama), "Diabetes Control" (Alaska), "Zoonosis Control" (Colorado), "Tuberculosis Control" (Florida), "Litter Control" and "Vector Control "(Hawaii), "Drug Control" (Maryland/Rhode Island), "AIDS Prevention and Control" (New Jersey), "Environmental Quality Control" and "Air Quality Control" (South Carolina), and "HIV and STD Control" (Texas). ${ }^{5}$

We can speculate about whether the term "tobacco control" helps or hinders our efforts. Or better yet, someone could do a bit of research to see what the term means to consumers, policy makers, and other targets of our work.

RONALD M DAVIS Editor

1 Dowd M. Speaking for House Speaker and enjoying the trappings. New York Times 1995; Jan 5: A1.

2 Random House dictionary of the English language: the unabridged edition. New York Random House, 1967.

3 Last JM, ed. Public health and preventive medicine (Maxcy-Rosenau), 12th ed. Norwalk Connecticut: Appleton-Century-Crofts, 1986.

$4 C D C$ and $A T S D R$ communications directory.
Atlanta, Georgia: Centers for Disease Control and Prevention/Agency for Toxic Substances and Disease Registry, October 1994

5 Association of State and Territorial Health Officials. 1994 Directory of state public healt agencies. Washington, DC: ASTHO, 1994.

\section{Smokers in Marvel Comics}

To the Editor - Marvel Comics has recently received praise from such sources as the New England fournal of Medicine (1994; 330: 1321) and the Columbia fournalism Review (January/February 1995: 20) because they cancelled trading cards showing characters (heroes and villains) smoking. In addition, trade advertisements stating "These Spokespeople will Never Smoke..." (published in Tobacco Control 1994; 3: 199) demonstrate Marvel's commitment to health via communication with kids. Marvel's comic books, however, the major communicator of the company, tell a different story.

A recent survey of the popular $X \mathrm{Men}$ titles, reveals an abundance of characters (the heroes, the role models) smoking. Some of these are established adult characters whose smoking is, unfortunately, part of their persona. "Wolverine", the mutant warrior, can smoke with impunity because he has a "healing factor" which protects him from harm. Teenagers, who consider themselves immune from the health effects of tobacco, will surely be consolled by this character. "Gambit," the Cajun thief, lives for adventure and risk-taking, and smoking enhances the image. Although the behaviour of these characters may be excused because they are adults, recent actions by Marvel have exceeded these limits when they introduced teenage smokers.

The new character of "Skin" is an egregious example of this (figure). $\mathrm{He}$ is a 16 -yearold, extremely ugly Hispanic teenager, insecure about his appearance, who gets by with attitude. Part of this "attitude" is his smoking behaviour. His character sends just the wrong message to teenage readers: if you're upset about your looks and your standing in the world, use tobacco to calm down/project a tough attitude. A recent issue of Generation Next (March 1995) takes this even further. Here we have "Shadowcat", a teenage character who is talented, tough, and beautiful. For no apparent reason (and in a change from her previous characterisation) we see her casually smoking after a fight scene. The message is clear: even respected, dominant teenagers smoke, either to relieve stress or for no reason at all.

Marvel characters are important figures to a huge number of children and youth. There is no reason that these heroes should be modelling dangerous, addictive behaviour to project images of idealised rebellion. I call on Marvel Comics to immediately change this behaviour in their comics as they have done in their trading cards. They owe it to their loyal public.

\section{MICHAEL LIPPMAN Washington DOC Seattle, Washington, USA}

In reply - Marvel Entertainment (including Marvel Comics) is owned by Ron Perelman, a cigar-smoking billionaire who also owns Consolidated Cigar Corporation. Perelman was featured on the cover of the Spring 1995 issue of Cigar Aficionado, which included an in-depth interview with him. - ED

\section{Women and tobacco}

To the Editor-We answered a letter from Deborah McLellan voicing dissatisfaction about the Ninth World Conference resolutions on 21 March 1995. Discovering that the letter has been published in the letters section of Tobacco Control, ${ }^{1}$ I would like to request that our response to her also be published in Tobacco Control. It is unfor-

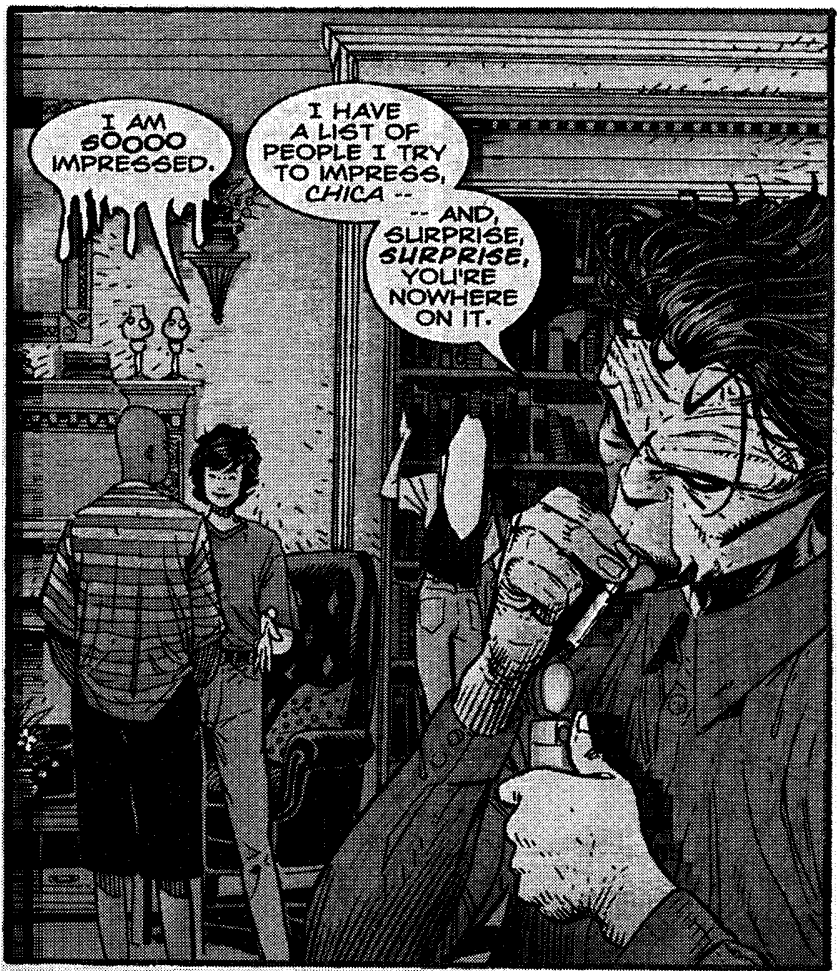

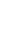

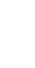

,

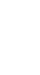

